\title{
Technology adoption and technical efficiency of smallholder farmers in Tolon district of Ghana: double bootstrap DEA approach
}

\author{
Benjamin Tetteh Anang ${ }^{1 *}$, Hamdiyah Alhassan² and Gideon Danso-Abbeam ${ }^{2}$ \\ ${ }^{1}$ Department of Agricultural Economics and Extension, Faculty of Agriculture, University for \\ Development Studies, Tamale, Ghana. \\ ${ }^{2}$ Department of Agricultural and Resource Economics, Faculty of Agribusiness and \\ Communication Sciences, University for Development Studies, Tamale, Ghana. \\ *Corresponding author: benjamin.anang@uds.edu.gh
}

\begin{abstract}
The study explored the impact of improved variety adoption on technical efficiency of smallholder maize farmers in Tolon District of northern Ghana. Smallholder maize farmers in the study area were sampled using random sampling technique. Double bootstrap data envelopment analysis was applied to estimate technical efficiency and its determinants. The results indicate that producers in the study area have a bias-corrected technical efficiency of $57 \%$ under variable returns to scale (VRS) assumption and 52\% under constant returns to scale (CRS) assumption. Controlling for potential endogeneity of the adoption variable, the results indicate that adoption of improved varieties enhance technical efficiency of maize farmers in the study area. Technical efficiency of the farmers increased with herd size but decreased with years of formal education, household size, extension contact, frequency of weeding, and farm size. Ensuring that improved seeds are made available and affordable to smallholder farmers and promotion of livestock rearing are policy measures likely to enhance technical efficiency of smallholder farmers.
\end{abstract}

Keywords: Adoption, bootstrapping, data envelopment analysis, technical efficiency, Tolon District. 


\section{Introduction}

Agricultural growth through higher productivity is one of the topical issues that have received global attention for the past decades, because of its effects on food and nutrition security (FNS) and long-term economic growth (Collier and Dercon, 2014). Typically, developed countries have been able to enhance agricultural productivity via the adoption of improved technologies and access to productivity-enhancing resources such as credit, land and markets. Improved agrarian technologies adopted include improved crop varieties, weed and pest management, modern machine and farm equipment and conservation agriculture (Reardon et al. 2009; Asfaw et al. 2012; Sheahan and Barrett, 2017). According to Lee (2005), adoption of agricultural technologies has the potential to increase farm yields, increase farmers' income and ensure food security. Despite, the benefits of improved agricultural technologies, adoption is low in most developing countries (Abebe et al., 2013; Jayne and Rashid, 2013; Sheahan and Barrett, 2017), including Ghana.

Ghana is an agrarian economy, with the agricultural sector providing jobs to about $71.3 \%$ of rural dwellers (Ghana Statistical Service, 2014a). In rural areas, where agriculture is the predominant livelihood, poverty and food and nutrition insecurity are rife (Ghana Statistical Service, 2014b). Agricultural development is therefore pivotal to eradicate poverty and enhance economic development. Indeed, promoting agricultural productivity has the potential to enhance the welfare of rural farm households through higher income (Asfaw et al., 2012; Kassie et al., 2013). Evidence suggests that adoption of improved agricultural technologies such as improved maize varieties with high yielding potential and adaptability to drought, and pest and diseases has the potential to increase productivity and thus improve welfare as well as food and nutrition security (Donkor $e t$ al., 2016; Sheahan and Barrett, 2017).

The government of Ghana has initiated policies and programmes to address the productivity challenges facing smallholder agriculture. For instance, the Food and Agriculture Sector Development Policy (FASDEP II) initiated in 2007, Ghana Shared Growth and Development Agenda (GSGDA 2010-2013), and Medium Term Agriculture Sector Investment Plan (METASIP 2010-2015) have all acknowledged the importance of boosting agricultural productivity of staple crops by providing farmers access to improved technologies and other productive resources such as credit and irrigation facilities. Recently, one of the comprehensive strategies set up is the Planting for Food and Jobs (PFJ) programme to focus on increasing the productivity of maize and other crops such as rice, soybeans, sorghum and vegetables through the provision of subsidized inputs such as fertilizer, improved seeds and extension services (MoFA, 2017).

In spite of these efforts, adoption of improved maize varieties is still low, and production is at the subsistence level. These have led to farm-level inefficiencies. Thus, efforts geared towards identifying the drivers of improved maize varieties and its effect on production efficiencies are critical in enhancing the productivity of farmers. This is because the efficient use of productive resources may contribute to sustainability and enhance agricultural production systems, and thus promote economic growth. This paper therefore aimed at examining the effect of adoption of improved maize varieties on farm efficiencies in the Tolon district of Northern region of Ghana.

Maize is Ghana's major staple food crop and the most significant source of food security (Wongnaa and Awunyo-Vitor, 2018). Also, maize production is an essential source of income in areas where it is cultivated and has featured significantly in most national public documents because it has the potential to enhance food security (MoFA, 2017). Despite these roles of maize, 
Ghana has experienced average shortfalls in domestic maize supplies. This is primarily due to low productivity as yields remain low around 1.99 metric tonnes per hectare for Ghanaian farmers in 2016 instead of an achievable yield level of 5.5 metric tonnes per hectare (MoFA, 2016; Andam et al., 2017).

A number of empirical studies have examined the effect of the adoption of improved agricultural technologies on farmers' technical efficiency level. Principal among such studies that are similar to this study are Asante et al. (2019), Azumah et al. (2019) and Rahman and Norton, (2019). The point of departure from this study is that, Asante et al. (2019) employed the metafrontier model and found adoption of fertilizer to increase maize farmers' technical efficiency level in Ghana. Azumah et al. (2019) applied the stochastic frontier analysis (SFA) and reported that adoption of irrigation system enhanced the technical efficiency level of rice farmers in Northern Ghana. Rahman and Norton (2019) also used the SFA and found adoption of integrated pest management (IPM) to have no effect on technical efficiency level of eggplant growers in Bangladesh. Nkegbe (2018) used the double bootstrap DEA approach to estimate the effect of credit on technical efficiency of smallholder farmers in Northern Ghana. The study was a pioneering work in terms of the estimation of technology adoption within a nonparametric technical efficiency framework in the context of Ghanaian agriculture. The study, however, did not account for endogeneity of credit in the second stage analysis. In this study, we extend the literature further to examine the effect of adoption of improved maize varieties on technical efficiency of maize farmers within a non-parametric framework, specifically the data envelopment analysis (DEA). Also, this study controls for endogeneity of adoption by including the predicted adoption scores rather that the observed adoption variable in the second stage truncated regression analysis.

\section{Literature review}

According to Coelli et al. (2002), technical efficiency (TE) is defined as the ability of an economic agent to use minimum amounts of inputs to achieve a given level of output (i.e. input-oriented), or for an economic agent to produce feasible maximum output from a given bundle of inputs (outputoriented). Theoretically, the two main approaches for measuring the technical efficiency of production firms or economic agents are stochastic frontier analysis (SFA) simultaneously developed by Aigner et al. (1977) and Meeusen and van der Broeck (1977), and data envelopment analysis (DEA) proposed by Charnes et al. (1978). According to Madau (2012), both methods achieve highly correlated results.

The SFA model is a parametric method and works under the assumption of a properly defined functional form of the frontier technology and inefficiency term, and can handle noisy data effectively (Aigner et al., 1977; Meeusen and van der Broeck, 1977; Kumbhakar et al., 2009). In contrast, DEA is a non-parametric method for estimating the relative efficiency of decision-making units (DMUs). The DEA model has two main advantages in estimating efficiency scores. First, no assumptions need to be made on the exact functional form between inputs and outputs, and second, distributional assumption of the inefficiency term is not required. The weakness of the DEA is its deterministic nature which makes it unable to separate the inefficiency component from statistical noise and/or measurement error.

Motivated by these arguments, various empirical studies have been conducted using the inputoriented DEA technique to examine the efficiency of firms or economic agents. A study in 
Bangladesh by Coelli et al. (2002) using the DEA approach observed that the mean technical, allocative and scale efficiency estimates of rice farmers were $69.4 \%, 81.3 \%$ and $94.9 \%$ respectively. In a similar study, Balcombe et al. (2008) used the DEA double bootstrap technique and found mean technical efficiency of $64.0 \%$ (at CRS) and 59\% (VRS) for rice farmers in Bangladesh. They observed that access to credit, extension and higher education increased farmers' technical efficiency whiles age decreased efficiency. Using the DEA double bootstrap, Wouterse (2010) found that continental migration increased technically efficiency of cereal farmers in Burkina Faso. Also, Mitra and Yunus (2018) applied the DEA double bootstrap technique and found the mean technical efficiency of tomato farmers in Bangladesh to be $83 \%$. The study revealed that efficiency increased with education, training but decreased with age. Also, adoption of local high yielding variety increased efficiency more than exotic high yielding variety.

In terms of empirical studies on the effect of adoption of agricultural technologies on technical efficiency level of farmers, different econometric techniques, crop types and agricultural technologies have been used with conflicting results. For example, Benedetti et al. (2019) based on the stochastic frontier analysis (SFA) found that adoption of fertigation system increased the level of technical efficiency among Italian farmers. In a similar study, Rahman and Norton (2019) applied SFA and found no significant effect of adoption of integrated pest management (IPM) on technical efficiency level of eggplant growers in Bangladesh. Using the metafrontier model, Asante et al. (2019) found that adoption of fertilizer increased the technical efficiency of maize farmers in Ghana. In their study, Azumah et al. (2019) employed the SFA correcting for sample selection bias and found adoption of irrigation system to increase the technical efficiency level of rice farmers in Northern Ghana.

\section{Methodology}

\subsection{Study area, sampling and data collection}

The study was conducted in the Tolon district of Northern Region, Ghana. Tolon is a rural district with majority of the people engaged in crop farming (97.5\% of households) and are predominately small-scale farmers. Maize is a major food crop and widely cultivated by the small-scale farmers. According to the 2010 population census, Tolon has an estimated population of 72,990 representing about $2.9 \%$ of the total population in the northern region of Ghana (Ghana Statistical Service, 2014c).

The district is characterized by a single rainy season, which starts in late April with little rainfall, rising to its peak in July-August and declining sharply and coming to a complete halt in OctoberNovember. The dry season starts from November to March with day temperatures ranging from 33 to $39^{\circ} \mathrm{C}$, while mean night temperature range from 20 to $26^{\circ} \mathrm{C}$. The mean annual rainfall ranges between 950 to $1,200 \mathrm{~mm}$. The main vegetation is grassland, interspersed with guinea savannah woodland, characterized by drought-resistant trees (Ghana Statistical Service, 2014c).

Primary cross-sectional data from 2018 farming season was collected with the help of semi-openended questionnaires. Multi-stage random sampling technique was used to select farm households for the study. First, eleven communities were randomly selected from the district. These 
communities were Cheyohi, Chirifoyili, Daasuyili, Dingoli, Gbanjong, Gundaa and Kpalsogu. The others include Kukuo, Kukuonaayili, Nyankpala and Woribogu Kukuo. In the second stage, based on the number of farm households in the selected communities, 25-48 farm households were selected from each community. A sample size of 340 maize farm households was selected for this study.

\subsection{Technology adoption model}

Following Khonje et al. (2015), farm households' decision to adopt improved maize varieties is analysed under the random utility theory. It posits that, rational economic agents (i.e. farm households) will choose to adopt improved maize varieties if the utility from adoption ( $\left.W_{i 1}\right)$ is greater than the utility from non-adoption $\left(W_{i 0}\right)$. However, the utilities are unobservable and the maximum benefit derived from adoption $\left(M_{i}\right)$ is a latent variable related to a set of farmer/farmspecific and institutional factors and is presented as equation (1):

$M_{i}=X_{i} \beta+\varepsilon_{i}$ with $M_{i}=\left\{\begin{array}{l}1 \text { if } M_{i}>0 \\ 0 \text { otherwise }\end{array}\right.$

Where $M_{i}$ is a binary variable that equals 1 if farmers adopt improved maize varieties and 0 otherwise, $\beta$ is a vector of parameters to be estimated, $X_{i}$ is a vector of farmer/farm-specific and institutional factors, $\varepsilon_{i}$ is an error term assumed to be normally distributed. Thus, the probability of adoption is presented as:

$\operatorname{Pr}\left(P_{i}=1\right)=\operatorname{Pr}\left(P_{i}^{*}>0\right)=\operatorname{Pr}\left(\varepsilon_{i}>-X_{i} \beta\right)=1-F\left(-X_{i} \beta\right)$

where $\mathrm{F}$ is the cumulative distribution function for $\varepsilon_{i}$. The binary nature of the dependent variable suggests that equation (2) is estimated using probit model (Wooldridge, 2010). Thus, $F$ exhibits cumulative distribution function of the standard normal distribution. Then the model to estimate the probability of observing a farmer adopting improved maize varieties is expressed as equation (3):

$P\left(Y_{i}=1 \mid x\right)=F\left(X_{i} \beta\right)=\int_{-\infty}^{X_{i} \beta} \frac{1}{\sqrt{2 \pi}} \exp \left(-\frac{z^{2}}{2}\right) d z$

Empirically, the probit model used to estimate adoption is represented as follows:

$Y_{i}=\beta_{0}+\sum_{n=1}^{11} \beta_{n} X_{n i}+u_{i}$

where $X_{i}$ is a vector of independent variables explaining adoption decisions, and $u_{i}$ is a random error term. The explanatory variables include farmer's age and its quadratic term, educational

level, household size, extension contact, degree of specialization in maize production, soil fertility status, access to credit, farmer group membership, herd size, and participation in off-farm work.

After obtaining the maximum likelihood estimates of the probit model, the predicted probability of adoption of IMV were estimated. This was used as an explanatory variable in the efficiency model in order to control for endogeneity.

\subsection{DEA model}

The study relies on the DEA model to estimate technical efficiency of maize production and how it is influenced by technology adoption in a nonparametric framework. Unlike, the parametric 
stochastic production frontier approach, the DEA approach does not assume a priori functional form for the input-output relationships and distributional assumptions of the inefficiency term (Farrell, 1957; Fraser and Cordina, 1999). Specifically, the DEA input-oriented model was adopted because maize farmers have more control over inputs rather than outputs. Following Farrell et al. (1957), the input-oriented measure of technical efficiency of individual farm unit or DMU is calculated by using the following model:

Minimize $T E_{j}$

Subject to; $\sum_{j=1}^{n} y_{j} \lambda_{j}-y_{j} \geq 0 ; \lambda_{j} \geq 0$ for $\nabla_{j}$,

$$
x_{i j} T E_{j}-\sum_{i=1}^{m} x_{i j} \lambda_{j} \geq 0
$$

where: $x_{i}, y_{j} \leq 0 ; \lambda_{j} \geq 0$ and $0 \leq T E \leq 1$

$T E_{j}$ is a scalar representing the technical efficiency scores of the $j$ th maize farmer or DMUs in the sample, $\lambda_{j}$ is the intensity variable or vector of weight of each farm that is not situated on the efficient frontier, while $x_{i j}$ is an $m \times n$ input matrix, representing the level of use of the $i$ th input on the $j$ th maize farm. $y_{j}$ is the level of output on the $j$ th maize farm. The objective function here is to minimize the proportion, $T E_{i}$, of inputs that farms in a peer group use to produce the same output level. This specification defines the constant returns to scale (CRS) technical efficiency score for each DMU, which is solved for each DMU in the sample. This satisfies the condition $T E_{i} \leq 1$, where a value of 1 indicates that the $j$ th farmer operates on the production frontier and thus fully efficient.

The above specification of a constant return to scale (CRS) DEA model is appropriate when all firms operate at optimal scale. The assumption of CRS is therefore regarded as restrictive. Coelli et al. (1998) argued that the variable return to scale (VRS) DEA model is more flexible. Thus, additional constraints of $\sum \lambda_{j}=1$ or $\sum \lambda_{j} \leq 1$ or $\sum \lambda_{j} \geq 1$ added to equation (5) allows for variable return to scale (VRS), decreasing returns to scale or increasing returns to scale.

The $T E_{i}$ are the estimated technical efficiency scores such that $1-T E_{i}$ is the proportion by which producers can potentially reduce utilization of inputs to attain the same level of output. The estimated TE scores, expressed as non-negative variables truncated above one, are used as the dependent variable in a second-stage truncated regression to estimate the determinants of technical efficiency. A notable feature of the Simar and Wilson approach is the double bootstrapping of the DEA scores to generate bias-corrected efficiency estimates. According to Simar and Wilson (2007), the bootstrap truncated regression model, unlike the traditional censored regression, corrects for serial correlation between the efficiency scores. The truncated regression model is expressed as;

$\widehat{T E}_{i}=\gamma_{0}+\sum_{j=1}^{11} \gamma_{j} Z_{j i}+w_{i}$

where $\widehat{T E}_{j}$ is the bias-corrected estimate of technical efficiency scores, $\varepsilon_{j} \sim\left(0, \sigma_{\varepsilon}^{2}\right)$ with right truncation at $1-Z_{j} \gamma, \gamma$ is a vector of parameters to be estimated, and $Z_{j}$ is a vector of farmer/farmspecific and institutional factors hypothesized to influence technical efficiency. The explanatory variables in the vector $Z_{i}$ include the predicted adoption score, farmer's age and its quadratic term, 
household size, educational level, degree of specialization in maize cultivation, engagement in offfarm work, farmer group membership, size of herd, farm size and frequency of weeding. These explanatory variables were adopted from previous studies (see Abebe et al., 2013; Kassie et al., 2013; Khonje et al., 2015; Asante et al., 2019; Azumah et al., 2019). To control for endogeneity of the adoption variable, the predicted adoption score was used as an explanatory variable in the efficiency model. For this study, 2000 bootstrap replications were used. The data were analysed using Stata version 15.

A common approach in the literature is to use Tobit regression in the second stage to assess the determinants of efficiency due to the fact that the efficiency scores are censored at 1 . Simar and Wilson (2007) identified two problems with this approach. The first problem is that the procedure lacks a well-defined data-generating process. Second, there are serious serial correlations between the estimated efficiency scores which make conventional approaches to statistical inference invalid. For instance, estimation of technical efficiency for a particular farm necessarily involves all other households that constitute the sample. Simar and Wilson (2007) therefore suggested truncated regression as a better approach for the second stage analysis.

The Simar and Wilson (2007) double bootstrap approach employs a data-generation process that seeks to address the identified problems using the DEA model specified in Equation (5) and the truncated regression model specified in Equation (6). The procedures for the double bootstrap DEA approach is as follows: (1) estimate standard DEA scores for all the farms using Equation (5); (2) Estimate the truncated regression using Equation (6); (3) calculate a set of bootstrap estimates; (4) compute the bias-corrected technical efficiency estimate for each farm; (5) use truncated regression to regress the bias-corrected technical efficiency scores on the set of explanatory variables; (6) conduct a number of bootstrap replications to provide a set of bootstrap estimates; (7) use the bootstrap estimates in steps 5 and 6 to construct confidence intervals for the technical efficiency scores and the truncated regression parameters.

\section{Results of the study}

\subsection{Description of the sample}

Table 2 describes the summary statistics of the sample according to adoption status. As indicated in the table, adopters had significantly higher maize output and used higher input quantities (labour, fertilizer, and agrochemicals) in production than non-adopters. There was no significant difference in farm size and amount of seed for adopters and non-adopters. As expected, the number of contacts with extension agents was higher for adopters of improved varieties. On the other hand, adopters allocated less of their total agricultural land to maize production. In other words, adopters had a lower degree of specialization in maize production in the study area. 
Table 2. Summary statistics of the variables included in the study

\begin{tabular}{|c|c|c|c|c|c|c|c|}
\hline \multirow[t]{2}{*}{ Variable } & \multicolumn{2}{|c|}{$\begin{array}{c}\text { Full sample } \\
(n=340)\end{array}$} & \multicolumn{2}{|c|}{$\begin{array}{l}\text { Adopters } \\
(n=144)\end{array}$} & \multicolumn{2}{|c|}{$\begin{array}{c}\text { Non-adopters } \\
(n=196)\end{array}$} & \multirow[t]{2}{*}{$\begin{array}{c}\text { Mean } \\
\text { diff. }\end{array}$} \\
\hline & Mean & $S D$ & Mean & $S D$ & Mean & $S D$ & \\
\hline \multicolumn{8}{|l|}{ Output and inputs variables } \\
\hline Maize output $(\mathrm{kg})$ & 1253 & 879 & 1373 & 1033 & 1165 & 737.6 & $207 * * *$ \\
\hline Farm size (acres) & 3.84 & 2.83 & 3.94 & 3.24 & 3.77 & 2.50 & 0.17 \\
\hline Quantity of seed (kg) & 21.72 & 14.71 & 20.91 & 15.54 & 22.31 & 14.07 & -1.40 \\
\hline Total labour (person-days) & 97.36 & 61.53 & 108.6 & 70.73 & 89.09 & 52.45 & 19.55 \\
\hline Quantity of fertilizer (kg) & 427.4 & 327.1 & 463.7 & 391.5 & 400.8 & 268.1 & 62.95 \\
\hline Total agrochemicals (litres) & 4.46 & 3.98 & 5.24 & 4.96 & 3.89 & 2.96 & 1.35 \\
\hline \multicolumn{8}{|l|}{ Socioeconomic variables } \\
\hline Age (years) & 38.44 & 11.96 & 39.75 & 11.09 & 37.47 & 12.50 & $2.28 * *$ \\
\hline Education (years) & 2.31 & 4.29 & 2.91 & 4.81 & 1.88 & 3.81 & $1.032 *$ \\
\hline Household size (count) & 10.40 & 5.09 & 10.38 & 5.23 & 10.41 & 5.00 & $-0.03 *$ \\
\hline Herd size (count) & 2.36 & 4.76 & 2.19 & 4.25 & 2.48 & 5.12 & -0.29 \\
\hline Off-farm work (= 1 if participant $)$ & 0.29 & 0.46 & 0.33 & 0.47 & 0.27 & 0.44 & $0.07 * *$ \\
\hline Degree of specialization & 52.00 & 18.45 & 49.20 & 18.98 & 54.05 & 17.82 & $-4.85 * *$ \\
\hline \multicolumn{8}{|l|}{ Policy/institutional variables } \\
\hline Extension contact (frequency) & 0.72 & 1.26 & 0.96 & 1.34 & 0.55 & 1.18 & 0.41 \\
\hline Credit access (= 1 if access) & 0.40 & 0.49 & 0.39 & 0.49 & 0.40 & 0.49 & -0.01 \\
\hline \multicolumn{8}{|l|}{ Farm-specific variables } \\
\hline Weeding (frequency) & 2.00 & 0.41 & 1.99 & 0.45 & 1.94 & 0.38 & 0.05 \\
\hline Soil fertility status (= 1 if fertile) & 0.54 & 0.50 & 0.54 & 0.50 & 0.54 & 0.50 & 0.001 \\
\hline
\end{tabular}

$* * *, * *$, and $*$ denote significant levels at $1 \%, 5 \%$ and $10 \%$, respectively.

The respondents had a mean farm size of 3.8 acres and average maize output of $1253 \mathrm{~kg}$. Furthermore, $42 \%$ of the respondents adopted improved maize varieties of rice, and 46.5 participated in a farmer group organization. The adopters of IMVs have a significantly higher average age (40 years) than the non-adopters (37 years). The average age of both groups implies that most of the sampled farmers are within their active and productive years. Adopters had more years of formal education and fewer members per household than non-adopters. Moreover, the proportion of adopters who engage in non-farm activities is significantly higher than the nonadopters. The respondents had approximately an average of a single extension contact during the cropping season with a minimum of zero and a maximum of five. The respondents also owned an average of 2 cattle and allocated $52 \%$ of total agricultural land to maize cultivation. Regarding access to agricultural credit, there is no significant difference between the proportion of adopters and non-adopters who accessed credit facility during the period under study. On average, maize farmers in the study area carried out a second weeding during the cropping season, while 54\% of the respondents perceived their soils to be fertile.

\subsection{Determinants of improved maize variety adoption}

Table 3 presents the maximum likelihood estimates of the parameters of the probit model of adoption. The age of the respondents had a positive relationship with adoption and was significant 
at $1 \%$. Older farmers, who are premised to be more experienced in production, are therefore more likely to adopt improved maize varieties. However, the quadratic term of the age variable indicates that adoption increases at a decreasing rate. In other words, beyond a certain threshold, adoption begins to decline with age. The positive relationship between age and adoption of IMV conforms to the studies of Anang (2019) and Danso-Abbeam et al. (2017b) in northern Ghana but disagrees with that Islam et al. (2012) conducted in the rice production sector in Bangladesh.

Table 3. Determinants of improved maize variety adoption

\begin{tabular}{llll}
\hline Variable & Coefficient & Std. Error & $P>|z|$ \\
\hline Age & $0.111^{* * *}$ & 0.032 & 0.000 \\
Age squared & $-0.001^{* * *}$ & 0.000 & 0.002 \\
Years of formal education & $0.043^{* *}$ & 0.017 & 0.013 \\
Household size & -0.012 & 0.015 & 0.421 \\
Degree of specialisation & $-0.009^{* *}$ & 0.004 & 0.028 \\
Extension contact & $0.239^{* * *}$ & 0.068 & 0.000 \\
Credit & 0.107 & 0.162 & 0.511 \\
Farmer group membership & $-0.336^{* *}$ & 0.166 & 0.043 \\
Herd size & 0.008 & 0.017 & 0.616 \\
Off-farm work & 0.165 & 0.159 & 0.299 \\
Soil fertility status & $0.354^{* *}$ & 0.173 & 0.041 \\
Constant & $-2.569^{* * *}$ & 0.757 & 0.001 \\
\hline
\end{tabular}

$* * *, * *$ and $*$ indicate statistical significance at $1 \%, 5 \%$ and $10 \%$ respectively. Log likelihood $=-$ 211.8; LR chi2 $(11)=39.71 ;$ Prob $>\mathrm{Chi}^{2}=0.000 ;$ Pseudo $\mathrm{R}^{2}=0.0857$.

Many empirical studies (see Anang 2019, Ahmed 2015, Deepa et al. 2015, Ghimire et al. 2015) on the adoption of agrarian technology have reported a significant and positive effect of formal education on adoption of farm technology. Consistent with these studies, farmers' years of formal education also had a positive correlation with adoption, implying that more years in formal education have a higher probability of influencing farmers' decision to cultivate IMV. On the other hand, farmers who allocated a higher proportion of their farmland to maize production were less likely to adopt improved varieties at a 5\% significance level. This is possible because most of our sampled farmers are smallholders who cultivate basically for household consumption and only sell the surpluses. Hence, they are more likely to grow the varieties (local variety) they have been consuming since time immemorial. Lunduka et al. (2012) also reported a negative and significant of farm size on the adoption of an open-pollinated variety of maize in Malawi.

Supply-driven variables such as extension services and farmer-based organizations (FBOs) are critical avenues for information dissemination on productivity-enhancing inputs such as IMV. As indicated by the results of the study, access to extension services enhanced adoption of improved varieties at $1 \%$ significance level. The positive and significant influence of extension services on the likelihood of adoption confirms the findings of many previous studies (Di Falco and Bulte 2011, Kassie et al. 2013, Kijima and Sserunkuuma 2013, Kassie et al. 2015). However, membership FBOs was negatively related to adoption of improved maize varieties at 5\% significance level, while farmers who perceived that their soils were fertile had higher probability of adopting improved varieties. 


\subsection{Results of the technical efficiency analysis}

Table 4 presents the original and the bias-corrected efficiency scores of the sampled rice farms under both CRS and VRS assumptions. In both cases, the bias-corrected scores are less than the initial scores suggesting that the original estimated efficiency scores were overestimated. The initial efficiency scores under CRS ranges from a minimum of 0.13 to a maximum of 1 , with an average efficiency score of 0.62, while the bias-corrected efficiency scores under CRS range from 0.1 to 0.91 with a mean score of 0.52 . With regards to farm efficiency under VRS, the original scores range from $0.21-1$ with an average score of 0.72 , while the estimated scores after bias correction range between 0.16 and 0.95 with a mean score of 0.57 .

Table 4. Distribution of technical efficiency scores

\begin{tabular}{lllll}
\hline Efficiency range & \multicolumn{2}{l}{ DEA CRS assumption } & \multicolumn{2}{c}{ DEA VRS assumption } \\
\cline { 2 - 5 } & Freq. & Percent & Freq. & Percent \\
\hline$\leq 0.20$ & 1 & 0.3 & 2 & 0.6 \\
$0.21-0.30$ & 9 & 2.6 & 15 & 4.4 \\
$0.31-0.40$ & 22 & 6.5 & 38 & 11.2 \\
$0.41-0.50$ & 67 & 19.7 & 79 & 23.2 \\
$0.51-0.60$ & 66 & 19.4 & 66 & 19.4 \\
$0.61-0.70$ & 68 & 20.0 & 60 & 17.6 \\
$0.71-0.80$ & 51 & 15.0 & 47 & 13.8 \\
$0.81-0.90$ & 37 & 10.9 & 17 & 5.0 \\
$0.91-1.00$ & 18 & 5.3 & 16 & 4.7 \\
Total & 340 & 100 & 340 & 100 \\
Efficiency scores & & & & \\
Mean & & & 0.57 & \\
Minimum & 0.52 & & 0.16 & \\
Maximum & 0.10 & 0.91 & 0.95 & \\
\hline
\end{tabular}

$\mathrm{CRS}=$ constant returns to scale; $\mathrm{VRS}=$ variable returns to scale

The findings of this study are comparable with results from previous studies. For example, Kirimov (2013) estimated non-bias and bias-corrected efficiency score of $67 \%$ and $59 \%$, respectively of potato farms in Uzbekistan. However, our results are lower than those obtained from Abatania et al. (2012), where non-bias and bias-corrected TE scores of $86 \%$ and $77 \%$ were estimated in agricultural farms in Northern Ghana. The table further revealed that 39\% had TE scores not exceeding 50\%, while $61 \%$ had efficiency scores exceeding 50\%. Besides, $23.5 \%$ of the respondents had TE levels exceeding $70 \%$. The results indicate the possibility to enhance the TE of maize farmers in the study area through improved allocation of resources in production.

\subsection{Determinants of technical efficiency}

Farmers' management style or practices serve as a guide for their inefficient counterparts to follow, hence the need to assess the sources of (in)efficiency in production. The determinants of technical efficiency among the respondents are presented in Table 5. Though the results from both CRS and VRS are presented, the focus of the discussion will be on the efficiency under the assumption of VRS (last two columns). This is because agricultural production is affected by many external factors, such as weather, economic shocks, and policy variables. Thus, it is not tenable to assume 
CRS for many farmers. The study followed Farrell's (1957) input-oriented approach in estimating the technical efficiency of the respondents. By this procedure, a positive coefficient of the explanatory variables corresponds to an increase in technical efficiency and vice versa. To control for endogeneity of the adoption variable, the predicted adoption scores rather than the actual (observed) values of adoption were used as the explanatory variable in the model. The result indicates that adoption is positively related to technical efficiency at $5 \%$ significance level. In other words, the adoption of improved varieties enhanced technical efficiency of maize production in the study area. The result of this study is supported by the findings of other authors such as Owusu (2016) who reported a $6 \%-8 \%$ increase in technical efficiency as a result of improved maize variety adoption by farmers in Ghana. Similarly, Ahmed et al. (2017) observed that adopters of improved maize variety in Ethiopia were $4.2 \%$ more technically efficient than non-adopters. Obayelu et al. (2016) also noted that Nigerian farmers who adopted improved protein maize had higher technical efficiency compared to non-adopters.

Table 5. Truncated regression estimates of the determinants of technical efficiency ${ }^{\varphi}$

\begin{tabular}{|c|c|c|c|c|}
\hline \multirow[t]{2}{*}{ Variable } & \multicolumn{2}{|c|}{ DEA CRS assumption } & \multicolumn{2}{|c|}{ DEA VRS assumption } \\
\hline & Coefficient & Bootstrap S.E. & Coefficient & Bootstrap S.E. \\
\hline Adoption score & $0.2014 *$ & 0.1188 & $0.2809 * *$ & 0.1188 \\
\hline Age & -0.0041 & 0.0061 & -0.0076 & 0.0059 \\
\hline Age squared & 0.0000 & 0.0001 & 0.0001 & 0.0001 \\
\hline Years of formal education & $-0.0057 * *$ & 0.0028 & $-0.0086^{* * *}$ & 0.0029 \\
\hline Household size & -0.0006 & 0.0019 & $-0.0034^{*}$ & 0.0019 \\
\hline Farm size & 0.0041 & 0.0039 & $-0.0146 * * *$ & 0.0042 \\
\hline Extension contact & -0.0138 & 0.0123 & $-0.0234 *$ & 0.0127 \\
\hline Farmer group membership & -0.0024 & 0.0225 & 0.0351 & 0.0234 \\
\hline Off-farm work & 0.0012 & 0.0216 & -0.0153 & 0.0221 \\
\hline Herd size & $0.0085 * * *$ & 0.0023 & $0.0065 * * *$ & 0.0024 \\
\hline Frequency of weeding & $-0.0939 * * *$ & 0.0244 & $-0.0706 * * *$ & 0.0247 \\
\hline Constant & $0.7219 * * *$ & 0.1167 & $0.8669 * * *$ & 0.1181 \\
\hline Sigma & $0.1607 * * *$ & & $0.1629 * * *$ & \\
\hline Wald chi-squared & $46.12 * * *$ & & $47.06 * * *$ & \\
\hline Total sample & 340 & & 340 & \\
\hline
\end{tabular}

Formal education is considered to be a critical human capital that improves people's ability, including farmers to acquire technical knowledge quickly, and subsequently pushes them closer to the frontier. However, our results indicate that years of formal education is negatively associated with farmers' technical efficiency at $1 \%$ significance level, suggesting that less formally educated farmers tend to be more technically efficient. This is contrary to the study's a priori expectation and a previous study conducted by Danso-Abbeam et al. (2017a) on maize production in the Northern region of Ghana. Similarly, household size was estimated to be negatively related to technical efficiency at $10 \%$ significance level. This implies that households with fewer members are more technically efficient than those with more members, possibly because, more members exert pressure on the limited cash resources available to the farm household. Moreover, the bigger the size of the family, the larger the dependency ratio, which could lead to this finding. The result 
is in line with the findings of Mango et al. (2015) that estimated a negative effect of household size on the technical efficiency of maize production in Zimbabwe.

Also, an increase in farm size lowered technical efficiency at $1 \%$ significance level. Thus, farmers with a relatively large tract of land tend to be technically inefficient. This suggests that the scale of operations is critical in production. Farmers with more extensive farmlands might have been operating beyond their scope (decreasing return to scale), which might lead to inefficient management of productive resources. The inverse relationship between farm size and technical efficiency was also estimated by studies such as Le et al. (2017), Etim and Udoh (2014), and Tien and Thong (2014) among crop farmers in Vietnam, Nigeria and Vietnam, respectively. However, Kirimov (2014) and Mango et al. (2015) reported contrary results to that of this study.

Contrary to a priori expectation, the frequency of agricultural extension has a significant negative influence on technical efficiency. As emphasized by many previous and recent empirical studies (Evenson 2001, Gautam 2001, Abdulai et al. 2017, Danso-Abbeam et al. 2018), agricultural extension service is a critical avenue for disseminating information on production technologies, which in turn, spur productivity in smallholder farming system. The negative influence of extension services could be because farmers did not receive the right information at the right time regarding maize production. Furthermore, the trust of extension agents may also play a critical role here. If farmers do not trust the information given to them by the extension agents, then they will not utilize these pieces of extension information, though received, which could lead to a negative effect on productivity. The results further indicate that herd size is positively related to technical efficiency at $1 \%$ significance level while weeding frequency negatively correlates with farmers' technical efficiency.

\section{Conclusion and recommendations}

In this study, we have estimated the effect of IMV on the efficiency of sampled farms in the Tolon District, Ghana. The result from the probit analysis indicated that the probability of adoption of IMV is shaped by the combined effects of age, years of formal education, extension contact, membership of farmer group, and perception of soil fertility status. The results from the DEA analysis showed a mean bias-corrected efficiency score of $57 \%$ under VRS assumption. The result suggests that output level could be increased by $43 \%$ without additional input requirements. The results from the second stage of the DEA (truncated regression model) indicate that the adoption of IMV has a significant and positive effect on the efficiency of the sampled farms in the study area. This suggests that adoption of IMV has been translated into improving the efficiency of maize production in the Tolon district of Ghana. Moreover, while years of formal education, household size, farm size, extension contact, and frequency of weeding have a significant and negative influence on TE, herd size significantly and positively affect TE.

From policy perspectives, this study has two insightful findings which can serve as empirical bases for the design and implementation of farm-level programmes. First, the fact that farmers' observed output lag behind their potential suggests that improvement in technical and managerial skill among these farmers is critical to boosting the productivity of maize farms. Second, farmers should be encouraged to plant improved varieties to enjoy the benefits that are associated with it. This could be achieved through the strengthening of the non-formal educational system where farmers are given the opportunity to learn some numeracy and management of their farms. Furthermore, 
ensuring farmers' access to subsidized fertilizer and improved maize seeds is expected to increase adoption and productivity of smallholder maize farmers.

\section{Declarations:}

\section{Availability of data and materials}

The datasets used and/or analysed during the current study are available from the corresponding author on reasonable request.

\section{Competing interests}

Authors declare there are no competing interests regarding this research

\section{Funding}

The authors received no direct funding for this research.

\section{Authors' contributions}

Benjamin Tetteh Anang conceptualized the research, conducted the data analysis and edited the manuscript. Hamdiya Alhassan wrote the introduction, literature review, materials and methods, and edited the manuscript. Gideon Abbeam-Danso discussed the results of the study and edited the manuscript. All authors read and approved the final version of the manuscript.

\section{Acknowledgment}

The authors are grateful to the farmers who participated in the study especially for their cooperation and willingness to provide information to the enumerators during the field survey.

\section{References}

Abdulai, S., Nkegbe, P. K., Donkoh, S. A. (2017). "Assessing economic efficiency of maize production in Northern Ghana", Ghana Journal of Development Studies, Vol. 14, No. 1, pp. 123145.

Abebe, G. K., Bijman, J., Pascucci, S. and Omta, O. (2013). "Adoption of improved potato varieties in Ethiopia: The role of agricultural knowledge and innovation system and smallholder farmers' quality assessment”, Agricultural Systems, Vol. 122, pp. 22-32.

Ahmed, M. H. (2015). "Adoption of multiple agricultural technologies in maize production of the Central Rift Valley of Ethiopia”, Studies in Agricultural Economics, Vol. 117, No. 3, pp. 162-168. https://doi.org/10.7896/issn.2063-0476

Ahmed, M. H., Geleta, K. M., Tazeze, A. and Andualem, E. (2017). "The Impact of improved maize varieties on farm productivity and wellbeing: evidence from the East Hararghe Zone of Ethiopia", Development Studies Research, Vol. 4, No. 1, pp. 9-21, https://doi.org/10.1080/21665095.2017.1400393. 
Aigner, D., Lovell, C. A. K., \& Schmidt, P. (1977). "Formulation and estimation of stochastic frontier production function models", Journal of Econometrics, Vol. 6, pp. 21-37.

Anang, B. T. (2019). "Are adopters of improved rice varieties more productive than non-adopters? empirical evidence from northern Ghana”, Ghana Journal of Development Studies, Vol. 16, No. 1, pp. 92-107. http://dx.doi.org/10.4314/gjds.v16i1.5.

Asante, B. O., Temoso, O., Addai, K. N., and Villano, R. A. (2019). "Evaluating productivity gaps in maize production across different agroecological zones in Ghana", Agricultural Systems, Vol. 176, pp. 102650.

Asfaw, S., Kassie, M., Simtowe, F., and Lipper, L. (2012). "Poverty reduction effects of agricultural technology adoption: A micro- evidence from rural Tanzania”, Journal of Development Studies, Vol. 48: pp. 1288-1305.

Azumah, S. B., Donkoh, S. A., and Awuni, J. A. (2019). "Correcting for sample selection in stochastic frontier analysis: insights from rice farmers in Northern Ghana", Agricultural and Food Economics, Vol. 7, No. 1, pp. 9. https://doi.org/10.1186/s40100-019-0130-Z

Balcombe, K., Fraser, I., Latruffe, L., Rahman, M. and Smith, L. (2008). “An application of the DEA double bootstrap to examine sources of efficiency in Bangladesh rice farming", Applied Economics, Vol. 40, No. 15, pp. 1919-1925.

Benedetti, I., Branca, G., and Zucaro, R. (2019). "Evaluating input use efficiency in agriculture through a stochastic frontier production: An application on a case study in Apulia (Italy)", Journal of Cleaner Production, Vol. 236, pp. 117609. https://doi.org/10.1016/j.jclepro.2019.117609.

Charnes, A., Cooper, W.W., and Rhodes, E. (1978). "Measuring the efficiency of decision-making units", European Journal of Operational Research, Vol. 2, No. 6, pp. 429-444.

Coelli, T. J., Rahman, S. and Thirtle, C. (2002). "Technical, allocative, cost and scale efficiencies in Bangladesh rice production: a non-parametric approach", Journal of Agricultural Economics, Vol. 53 (3), pp. 607-626.

Coelli, T. J., Rao, D. S. P., and Battese, G. E. (1998). "An introduction to efficiency and productivity analysis”, Boston, Kluwer Academic Publishers.

Collier, P. and Dercon, S. (2014). "African agriculture in 50 years: smallholders in a rapidly changing world?”, World Development, Vol. 63, pp. 92-101.

Danso-Abbeam, G., Abban, A. A. B. and Donkoh, S. A. (2017). "Off-farm participation and technical efficiency among smallholder farmers in the Northern Region, Ghana", Applied Studies in Agribusiness and Commerce, Vol. 11, No. 1-2, pp. 35-44.

Danso-Abbeam, G., Bosiako, J. A., Ehiakpor, D. S., Mabe, F. N. (2017). "Adoption of improved maize variety among farm households in the northern region of Ghana", Cogent Economics and Finance, Vol. 5, No. 1, pp. 1416896. https://doi.org/10.1080/23322039.2017.1416896. 
Danso-Abbeam, G., Ehiakpor D. S., and Aidoo, R. (2018). "Agricultural Extension and its Effects on productivity and Farm Income: Insight from Northern Ghana", Agriculture and Food Security, Vol. 7, No. 4.

Deepa, R., Bandyopadhyay, A. K., and Mandal, M. (2015). "Factors related to adoption of maize production technology in Cooch Behar district of West Bengal", Agriculture, Vol. 5, No. 2, pp. $775-777$.

Di Falco, S., and Bulte, E. (2011). "A dark side of social capital? Kinship, consumption, and savings", Journal of Development Studies, Vol. 47, No. 8, pp. 1128-1151.

Donkor, E., Owusu-Sekyere, E., Owusu, V and Jordaan, H. (2016). "Impact of row-planting adoption on productivity of rice farming in northern Ghana", Review of Agricultural and Applied Economics, Vol. 19, pp. 19-28.

Etim, N. A. A. and Udoh, E. J. (2014). "Identifying sources of efficiency among resource poor indigenous vegetable farmers in Uyo, Nigeria", International Journal of Food and Agricultural Economics, Vol. 2: pp. 33-39.

Evenson, R. (2001). "Economic Impacts of Agricultural Research and Extension”, In Gardner, B. and Rausser, G. Handbook of Agricultural Economics, Vol. 1, pp. 573-628.

Farrell, M. J. (1957). "The measurement of productive efficiency", Journal of the Royal Statistical Society. Series A (General), Vol. 120, No. 3, pp. 253-290.

Fraser, I. and Cordina, D. (1999). "An application of data envelopment analysis to irrigated dairy farms in northern Victoria, Australia", Agricultural Systems, Vol. 59, pp. 267-282.

Gautam, M. (2000). "Agricultural Extension: The Kenyan Experience, an Impact Evaluation", Washington, D. C., The World Bank.

Ghana Statistical Service (2014a). "Ghana Living Standards Survey Round 6 (GLSS6)", GSS, Accra.

Ghana Statistical Service (2014b). "GLSS 6 poverty profile in Ghana: 2005-2013", Ghana Statistical Service, Accra, available at www.statsghana.gov.gh/docfiles/glss6/GLSS6_Poverty\%20Profile\%20in\%20Ghana.pdf.

Ghana Statistical Service (2014c). "2010 Population and Housing Census: District Analytical Report, Tolon-Kumbungu District”, GSS, Ghana.

Ghimire, R., Wen-chi, H. and Shrestha, R.B. (2015). "Factors affecting adoption of improved rice varieties among rural farm households in Central Nepal", Rice Science, Vol. 22, No. 1, pp. 35-43.

Islam, K. Z., Sumelius, J., \& Backman, S. (2012). "Do differences in technical efficiency explain the adoption rate of HYV rice: Evidence from Bangladesh", Agricultural Economics Review, Vol. 13, No. 1, pp. 93-104.

Jayne, T. S., and Rashid, S. (2013). "Input subsidy programs in sub-Saharan Africa: A synthesis of recent evidence", Agricultural Economics, Vol. 44, No. 6, pp. 547-562. 
Kassie, M., Jaleta, M., Shiferaw, B., Mmbando, F., and Mekuria, M. (2013). "Adoption of interrelated sustainable agricultural practices in smallholder systems: Evidence from rural Tanzania", Technological Forecasting and Social Change, Vol. 80, No. 3, pp. 525-540.

Kassie, M., Teklewold, H., Jaleta, M., Marenya, P. and Erenstein, O. (2015). "Understanding the adoption portfolio of sustainable intensification practices in eastern and southern Africa", Land Use Policy, Vol. 42, No. 2015, pp. 400-411.

Khonje, M., Manda, J. Alene, A.D. and Kassie, M. (2015). "Analysis of adoption and impacts of improved maize varieties in Eastern Zambia”, World Development, Vol. 66, pp. 695-706

Kijima, Y. and Sserunkuuma, D. (2013). "The adoption of NERICA rice varieties at the initial stage of the diffusion process in Uganda", African Journal of Agricultural and Resource Economics, Vol. 8, No. 1, pp. 45-56.

Kumbhakar, S., Tsionas, E. and Sipiläinen, T. (2009). "Joint estimation of technology choice and technical efficiency: an application to organic and conventional dairy farming", Journal of Productivity Analysis, Vol. 31, No. 3, pp. 151-161.

Lee, D. R. (2005). “Agricultural sustainability and technology adoption: issues and policies for developing countries", American Journal of Agricultural Economics, Vol. 87, No. 5, pp. 13251334

Lunduka, R., Fisher, M., and Snapp, S. (2012). "Could farmer interest in a diversity of seed attributes explain adoption plateaus for modern maize varieties in Malawi?", Food Policy, Vol. 37, pp. 504-510. https://doi.org/10.1016/j.foodpol.2012.05.001.

Meeusen, W. and Van den, B. J. (1977). "Efficiency estimation from cobb-Douglas production functions with composed error", International Economic Review, Vol. 18, pp. 435-444. https://doi.org/10.2307/2525757.

Mitra, S. and Yunus, M. (2018). "Determinants of tomato farmers' efficiency in the Mymensingh district of Bangladesh. Data envelopment analysis approach", Journal of Bangladesh Agricultural University, Vol. 16, No. 1, pp. 93-97. https://doi.org/10.3329/jbau.v16i1.36487.

MoFA (Ministry of Food and Agriculture) (2016). "Agriculture in Ghana. Facts and Figures 2015”, Statistics, Research and Information Directorate (SRID), October 2016. Accra, Ghana.

MoFA (Ministry of Food and Agriculture) (2017). "Planting for Food and Jobs, Strategic Plan for Implementation (2017-2020)", Republic of Ghana.

Nkegbe, P. K. (2018). Credit access and technical efficiency of smallholder farmers in Northern Ghana: Double bootstrap DEA approach. Agricultural Finance Review, Vol. 78, No. 5, pp. 626639.

Obayelu, A. E., Moncho, C. M. D. and Diai, C. C. (2016). "Technical efficiency of production of quality protein maize between adopters and non-adopters, and the determinants in Oyo State, Nigeria", Review of Agricultural and Applied Economics, Vol. XIX, No. 2, pp. 29-38. https://doi.org/10.15414/raae/2016.19.02.29-38. 
Owusu, V. (2016). "Technical efficiency of technology adoption by maize farmers in three agroecological zones of Ghana", Review of Agricultural and Applied Economics. Vol. XIX, No. 2, pp. 39-50. https://doi.org/10.15414/raae/2016.19.02.39-50.

Rahman, S. Md., and Norton, G.W. (2019). "Farm-level impacts of eggplant integrated pest management: a stochastic frontier production function approach", International Journal of Vegetable Science, Vol. 25, No. 6, pp. 590-600. https://doi.org/10.1080/19315260.2019.1566188.

Reardon T., Barrett, C. B., Berdegué, J. A., and Swinnen, J. F. (2009). "Agrifood industry transformation and small farmers in developing countries. World Development, Vol. 37, No. 11, pp. 1717-1727.

Sheahan, M., and Barrett, C. B. (2017). "Ten striking facts about agricultural input use in SubSaharan Africa. Food policy, Vol. 67, pp. 12-25. https://doi.org/10.1016/j.foodpol.2016.09.010.

Simar, L. and Wilson, P. W. (2007). "Estimation and inference in two-stage, semi-parametric models of production processes. Journal of Econometrics, Vol. 136, No. 1, pp. 31-64.

Tien, N.V. and P.L. Thong (2014). "Analyzing economic efficiency of the lotus farms in Dong Thap Province (in Vietnamese)", Scientific Journal of Can Tho University, Vol. 30: pp. 120-128.

Wongnaa, C. A. and Awunyo-Vitor, D. (2018). "Achieving sustainable development goals on no poverty and zero hunger: Does technical efficiency of Ghana's maize farmers matter?", Agriculture \& Food Security, Vol. 7, No. 71. https://doi.org/10.1186/s40066-018-0223-Z.

Wooldridge, J. M. (2010). "Econometric analysis of cross section and panel data", 2nd edition, Cambridge, MA: MIT Press.

Wouterse, F. (2010). "Migration and technical efficiency in cereal production: evidence from Burkina Faso", Agricultural Economics, Vol. 41, No. 5, pp. 385-395. 